\title{
Kryzys władzy i etniczne przebudzenie. Zmiany kulturalne i społeczne w Azerbejdżanie w epoce Chruszczowa.
}

KPZR Nikita Chruszczow wystąpił z tajnym referatem zatytułowanym O kulcie jednostki $i$ jego następstwach ( $О$ культе личности и его последствия). Referat potępiający kult jednostki odsłaniał ogrom i brutalność represji, czystek w szeregach partii stosowanych przez poprzednie kierownictwo. Był to początek ery, która zapisała się w historii jako odwilż chruszczowowska; podjęto wtedy próbę reform i zmian zarówno w sferze partyjnopolitycznej, jak i społeczno-gospodarczej ${ }^{103}$. Idea rewizji polityki wodzowskiej była odebrana wśród inteligencji jako demokratyzacja socjalizmu, rozluźniająca duszącą pętlę totalitaryzmu. Jednak z punktu widzenia obecnej wiedzy na temat wydarzeń, jakie zaszły na Węgrzech w 1956 roku oraz w poszczególnych republikach radzieckich w drugiej połowie lat 50., można sądzić, że procesy te były niezamierzonymi efektami destalinizacji ${ }^{104}$, a Chruszczow nie był świadomy siły fali, jaką uruchomił ${ }^{105}$. Niezależnie od zamierzonych celów polityka rewizjonizmu skutkowała wzrostem nastrojów antysowieckich i narodowych w republikach radzieckich, również w Azerbejdżańskiej Socjalistycznej Republice Radzieckiej.

Po XX Zjeździe w Azerbejdżanie, podobnie jak w innych republikach, rozpoczęła się szeroka propagandowa kampania mająca na celu rozpowszechnienie wniosków płynących z tajnego referatu Chruszczowa. Wszystkie komitety partyjne w miastach i rejonach dostały nakaz zorganizowania w zakładach pracy spotkań z robotnikami, członkami partii w celu zapoczątkowania publicznej debaty na temat kultu jednostki. Ciekawa jest analiza skutków tej polityki na Kaukazie Południowym. Gruzińskie społeczeństwo zareagowało na nową narrację

\footnotetext{
${ }^{103}$ D. Filtzer, The Khrushchev Era: De-Stalinization and the Limits of Reform in the USSR 1953-64, Macmilian, Londyn 1993; P. Jones, From the secret speech to the burial of Stalin: real and ideal responses to deStalinization, [w:] P. Jones (red.), The Dilemmas of De-Stalinization: Negotiating Cultural and Social Change in the Khrushchev era, Routledge, Londyn 2006, s. 41-63; W. Taubman, Chruszczow. Człowiek i epoka, thum., Łukasz Witczak, Bukowy Las, Wrocław 2012.

104 Termin „destalinizacja” w znaczeniu rehabilitacji ofiar stalinizmu oraz reform polityczno-społecznych pojawił się dopiero w okresie postsowieckim oraz w zachodniej myśli politycznej. Za czasów Chruszczowa przy rewizji poprzedniego kursu linii politycznej używano bezosobowych określeń, nie wymieniając wprost Stalina. P. Jones, Introduction: the dilemas od De-Stalinization, w: Polly Jones (ed.), The Dilemmas of De-Stalinization: Negotiating Cultural and Social Change in the Khrushchev era, Routledge, Londyn 2006, s. 2-3.

105 D. A. J. Reynolds, Revising History in Communist Europe: Constructing Counter-Revolution in 1956 and 1968, Althem Press, Nowy Jork 2020, s. 33.
} 
masowymi demonstracjami, zwanymi wydarzeniami marcowymi. W trzecią rocznicę śmierci Stalina, w 1956 roku, doszło do masowych wystąpień w jego obronie. Krytyka Stalina i Berii została odebrana przez ich rodaków ,,jako jednoznaczna zapowiedź końca specjalnego statusu Gruzji i jej degradację z «awansującego faworyta» do jakieś innej, niższej kategorii”,106, powodując gniew i frustrację Gruzinów. Czwartego marca 1956 roku ludzie zaczęli gromadzić się przy pomniku Stalina w Tbilisi. W dniach 5-9 marca w wielu miastach Gruzji, w Gori, Kutaisi, Batumi, Suchumi, podczas demonstracji zgromadziły się wielotysięczne tłumy, ,oddające hołd Stalinowi i wygłaszające hasła narodowe. Dziewiątego marca liczba protestujących na placu Stalina (później Lenina) sięgnęła 70 tysięcy osób. W przemówieniach padały skrajne żądania, takie jak: dymisja Chruszczowa i przewodniczącego Rady Ministrów Nikołaja Bułganina, mianowanie etnicznie gruzińskich komunistów, w tym syna Stalina Wasilija, na kierownicze stanowiska w centralnych władzach ${ }^{107}$. Gdy do protestujących studentów dołączyli uczniowie, w Tbilisi zostały zamknięte uczelnie i szkoły, stanęły zakłady pracy. Stolicę Gruzji ogarnął chaos, Moskwa straciła cierpliwość. Dziewiątego marca do miasta weszły wojsko i czołgi. Żołnierze otworzyli ogień z broni automatycznej do demonstrujących, w skutek czego życie straciło 21 ludzi, 54 osoby zostały ranne, a kilkaset osób trafiło do aresztu ${ }^{108}$.

W Armeńskiej SRR odwilż chruszczowowska nasiliła debatę na temat „wielkiej Armenii”, w tym rewizjonistyczne żądania wobec Turcji oraz terytorialne pretensje wobec sąsiednich republik. Dekret Chruszczowa przekazujący w 1954 roku Krym Ukraińskiej SRR dał nadzieję ormiańskiej inteligencji oraz Kościołowi ormiańskiemu na przekazanie Armenii azerbejdżańskich regionów Górskiego Karabachu oraz Nachiczewania. Kwestia ta została zawarta w pismach głowy Ormiańskiej Cerkwi katolikosa Vazgena I do przewodniczącego Rady Ministrów ZSSR Bułganina. W jednym z dwóch listów wysłanych 12 maja 1956 roku katolikos, zdając sprawozdanie ze swojego trzymiesięcznego pobytu za granicą, w głównych skupiskach diaspory ormiańskiej w Libanie, Syrii, Egipcie oraz Francji, wyraził oczekiwania swoich rodaków na „sprawiedliwe rozstrzygnięcie kwestii ormiańskiej”, czyli na przyłączenie do Armeńskiej SRR azerbejdżańskich regionów Karabachu i Nachiczewańskiej ASRR oraz prowincji Achalkalaki na południu Gruzji. Vazgen I wyraził nadzieję, jaką ormiańska diaspora pokładała $\mathrm{w}$ rządzie radzieckim w kwestii zapewnienia niezbędnych warunków terytorialnych, gospodarczych i mieszkaniowych, warunkujących ich repatriację do ZSSR. Na koniec listu katolikos Ormiańskiej Cerkwi przedstawił argumenty stricte polityczne, które mogłyby skłonić Moskwę do rewizji granic.

\footnotetext{
${ }^{106}$ T. Blauvelt, Zmiana statusu i etniczna mobilizacja podczas wydarzeń marca 1956 roku w Gruzji, „Wolność i Solidarność", 2019, nr 6, s. 50. Artykuł dostępny również na stronie: https://www.civitas.edu.pl/wpcontent/uploads/2016/11/Zmiana-statusu-i-etniczna-mobilizacja-podczas-wydarzen-marca-1956-roku-wGruzji1.pdf [18.02.2020].

${ }^{107}$ Ibidem, s. 52.

${ }^{108}$ Ibidem, s. 51.
} 
Pozwolę odważyć się dodać taka prawdę, że o ile w Zakaukaziu silne będa ormiański naród $i$ Armenia, o tyle będzie zapewnione bezpieczeństwo poludniowych granic naszej Wielkiej Ojczyzny ${ }^{109}$.

Azerbejdżańskie władze zareagowały na XX Zjazd wzmożeniem retoryki narodowej, czego uwieńczeniem było dodanie w konstytucji w sierpniu 1956 roku zapisu o statusie języka azerbejdżańskiego jako urzędowego. Dyskusja o języku była jednym z czynników, które legły $\mathrm{u}$ podstaw szerszego procesu upolitycznienia narodowej tożsamości przez kierownictwo partii i azerbejdżańską inteligencję. XX Zjazd uruchomił również przewartościowanie literatury oraz historii, zwłaszcza początku XX wieku, czyli okresu sowietyzacji kraju. W latach 1954-1959 w republice doszło do aktywizacji życia politycznego, a przede wszystkim dyskusji na temat języka azerbejdżańskiego, jego statusu, na temat azerbejdżańskiej literatury i przewartościowania wydarzeń lat 20.

Po śmierci Stalina pierwszy sekretarz KC AzPK Mir Dżafar Bagirov (1933-1953), człowiek Berii, który wywodził się z Czeka, został usunięty ze stanowiska i na krótki okres objął tekę przewodniczącego Rady Ministrów republiki. Po areszcie i śmierci Ławrientija Berii los Bagirova był przesądzony. W 1954 roku został on wykluczony z partii i aresztowany. W 1956 roku po dwutygodniowym procesie na mocy decyzji Kolegium Wojskowego Sądu Najwyższego ZSSR Bagirov został skazany na śmierć. Tym samym nadszedł symboliczny koniec epoki wielkiego terroru w Azerbejdżanie, zwanej „bagirowszczyna" ${ }^{, 10}$.

Ekipa, która doszła do władzy w 1954 roku, nie była związana z organami bezpieczeństwa. Pierwszym sekretarzem AzPK został Imam Mustafayev, doktor, specjalista nauk rolniczych. Kandydatura ta wpisywała się w politykę kadrową Chruszczowa, który ciężar władzy przesunął $\mathrm{z}$ organów bezpieczeństwa na partyjne struktury. Kolejną ciekawą $\mathrm{i}$ ważną decyzją była nominacja pisarza o dużym autorytecie społecznym, Mirzy Ibrahimova, w marcu 1954 roku na stanowisko przewodniczącego Prezydium Rady Najwyższej Azerbejdżańskiej SRR. Podczas analizy decyzji, jakie podejmowała nowa elita, która doszła do władzy w okresie odwilży, powstaje pytanie, jak było możliwie po trudnych latach ideologicznej indoktrynacji i narracji jednolicącej nierosyjskie narody ukształtowanie się grupy osób, która w swoich aspiracjach tożsamościowych doszła tak daleko, że aż popadła w konflikt z Centrum. Przecież ci ludzie nie pojawili się spoza systemu, wręcz byli jego tworem. Odpowiedź na to pytanie paradoksalnie może tkwić w wydarzeniach, jakie zaszły podczas rządów Bagirova, a konkretnie w wojennej kampanii rozpoczętej przez Stalina wobec Iranu w latach 1941-1946. Wtedy właśnie Bagirov, korzystając z koniunktury, obecności wojsk

\footnotetext{
${ }^{109}$ A. Gaziian (oprac. i red.), Pis'ma Katolikosa vsekh armian Vazgena I Predsedateliu Soveta Ministrov SSR N. A. Bulganinu, „Patma-Banasirakan Handes” (Historyczno-Filologiczne Pismo), 2000, nr 2, s. 255. Publikacja dostępna również na stronie http://hpj.asj-oa.am/4518/1/2000-2(249).pdf [18.02.2020].

$110 \mathrm{Na}$ temat wielkiego terroru w Azerbejdżanie patrz: E. Ismailov, Istoria „,bolshogo terrora” $w$ Azerbaidzhanie, Rosspen, Moskwa 2015; E. Ismailov, Soviet State Terrorism in Azerbaijan, „The Caucasus and Globalization", 2010, t. 4. nr 1-2, s. 163-172.
} 
Czerwonej Armii w Iranie, wysyłał specjalistów, przedstawicieli inteligencji, by wywołali separatyzm przez wzmocnienie odrębności narodowej irańskich Azerów ${ }^{111}$.

Można przypuszczać, że angażując się w budowanie komunistycznego, ale jednak azerbejdżańskiego rządu w Iranie, przedstawiciele azerbejdżańskiej inteligencji, tacy jak Mirza Ibrahimov czy poeta Rasul Rza, poczuli euforię narodowego państwa. Podczas gdy w radzieckim Azerbejdżanie nie mogli wspominać o rusyfikacji, w Tebrizie głośno mówili o szowinizmie perskim, budząc tym samym świadomość narodową irańskich Azerów. W Azerbejdżanie Irańskim, azerbejdżańscy pisarze i poeci, nie odczuwając duszącej radzieckiej cenzury, poruszali politycznie kontrowersyjne tematy, takie jak jedność Azerbejdżanu, demokratyzacja rządu, budowanie państwa narodowego. W Tebrizie ich zadaniem było wręcz wzmożenie świadomości narodowej azerbejdżańskich mieszkańców w warunkach konfrontacji z rządzącą w Iranie perską dynastią Pachlawi. Wspomniany wyżej Mirza Ibrahimov w 1945 roku kierował grupą pracowników politycznych delegowanych do Tebrizu oraz był pierwszym redaktorem gazety „Za Ojczyznę”, którą wydawano w języku azerbejdżańskim rzekomo dla żołnierzy Armii Czerwonej, choć w rzeczywistości była adresowana do mieszkańców azerbejdżańskich prowincji Iranu ${ }^{112}$. Pierwszy sekretarz KC Imam Mustafayev również był delegowany w 1944 roku do Azerbejdżanu Irańskiego w celu modernizacji rolnictwa ${ }^{113}$.

W Azerbejdżanie namiastką zmian było nasilenie prac nad reformą alfabetu. W 1954 roku decyzją Rady Ministrów Azerbejdżanu została wydana książka Ortografia języka azerbejdżańskiego. Rok później, w 1955 roku, Instytut Literatury i Języka Akademii Nauk przedstawił projekt zmian w ortografii ${ }^{114}$. W projekcie zwrócono uwagę na błędy popełnione podczas przejścia z łacińskiego zapisu na cyrylicę w 1940 roku. Wtedy do alfabetu azerbejdżańskiego przy zapisie umlautów „ö” „,̈” zastosowano rosyjskie litery „ë” „ю”, a dla zakodowania fonemu ,ə” określanego w międzynarodowym systemie fonetycznym jako „szwa” użyto literę „,". Warte jest podkreślenia, że ten fonem jest charakterystyczny i wyróżnia azerbejdżański wśród innych języków turkijskich. Pod tym względem jego zapis ma polityczny, a nawet tożsamościowy wydźwięk.

Praca nad zapisem alfabetu doprowadziła do dyskusji na temat statusu języka. Osoby posługujące się azerbejdżańskim czuły się dyskryminowane pod względem języka w radzieckim Azerbejdżanie, w którym stanowiły etniczną większość. We wszystkich ministerstwach, urzędach, organach ścigania obowiązującym językiem był rosyjski. Kraj był podzielony między rosyjskojęzyczne administracyjne Baku a resztę regionów, gdzie posługiwano się językiem azerbejdżańskim. W praktyce oznaczało to, że zarówno cała dokumentacja urzędowa, medyczna, jak i listy, wnioski, skargi napisane po azerbejdżańsku nie były rozpatrywane. Warto zaznaczyć, że nauka azerbejdżańskiego nie była obowiązkowa dla uczniów szkół rosyjskich, co dodatkowo obniżało publiczną wartość języka, spychając go na margines. Tę kwestię regulowało rozporządzenie przewodniczącego Rady Ministrów

\footnotetext{
111 Dzh. Gasanli, SSSR - Iran: Azerbaidzhan'skij krizis i nachalo kholodnoj vojny (1941-1945 gg.), Geroi Otechestva, Moskwa 2006, s. 24, 50.

112 Ibidem, s. 31.

113 Ibidem, s. 52, 54.

114 Dzh. Gasanli, Khrushchevskaia „ottepel'” i natsional'nij vopros v Azerbaidzhane (1954-1959), Flinta, Moskwa 2009, s. 18.
} 
ZSSR Nikołaja Bułganina z 9 maja 1955 roku: W republikach związkowych (z wyjątkiem RFSRR) należy zwolnić uczniów szkół podstawowych, siedmioletnich i średnich od obowiązku nauki języka rdzennej ludności, jeżeli język ten nie jest dla nich ojczysty i nauczanie nie jest prowadzone w języku [rdzennej większości - SK] tej republiki ${ }^{115}$. Rodzice chętnie korzystali z tego prawnego instrumentu, zwalniając swoje pociechy z dodatkowych zajęć, które były traktowane jako fakultatywne. Takie rozwiązanie jeszcze bardziej obniżyło prestiż języka, szczególnie w kosmopolitycznym Baku, gdzie do rosyjskich szkół uczęszczały dzieci o różnej narodowości. Dodajmy jeszcze, że azerbejdżańscy uczniowie zaczynali naukę ojczystego języka dopiero w piątej klasie, co negatywnie rzutowało również na jakość kształcenia. Etniczni Azerbejdżanie, świadomi tych wad, w trosce o przyszłą karierę potomstwa mimo wszystko wybierali rosyjskie szkoły, gdyż osoby, które nie władały biegle językiem rosyjskim w mowie i piśmie, nie miały dostępu do kierowniczych stanowisk, pracowały jako niskokwalifikowani pracownicy mimo posiadanego dyplomu.

Czternastego sierpnia 1956 roku Biuro KC AzPK przyjęło uchwałę „O nauczaniu języka azerbejdżańskiego w szkołach Azerbejdżańskiej SRR z językami rosyjskim, ormiańskim i gruzińskim". Uchwała miała wejść w życie w roku szkolnym 1956/1957, co było sprzeczne z wyżej wspomnianym rozporządzeniem Bułganina z 1955 roku $^{116}$. Niewątpliwie dla azerbejdżańskiego kierownictwa partyjnego kwestia uregulowania statusu języka azerbejdżańskiego było ambitnym wyzwaniem, chociażby $\mathrm{z}$ tego powodu, że $\mathrm{w}$ tekstach konstytucji sąsiednich Gruzji ${ }^{117}$ i Armenii ${ }^{118}$ z 1937 roku znalazły się zapisy o tym, że językiem urzędowym w tych republikach był odpowiednio gruziński i ormiański ${ }^{119}$. Z tej racji poziom rusyfikacji życia publicznego w Azerbejdżanie w porównaniu z sąsiednimi krajami kaukaskimi był bardzo duży. Kontynuując reformy Rada Najwyższa republiki przyjęła w sierpniu 1956 roku ustawę o zmianach w tekście Konstytucji Azerbejdżańskiej SRR artykułu 151 o języku państwowym. „W Azerbejdżańskiej SRR językiem urzędowym jest język azerbejdżański. Mniejszościom narodowym mieszkającym na terytorium Azerbejdżańskiej RRS przysługuje prawo rozwoju swobodnego posługiwania się ojczystymi językami zarówno w swoich placówkach kulturalnych, jak i urzędach państwowych" ${ }^{\text {120 }}$. Po przyjęciu ustawy o języku urzędowym wprowadzono okres przejściowy sześciu miesięcy, w ciągu których osoby zatrudnione w administracji publicznej musiały się nauczyć języka azerbejdżańskiego. Jednocześnie był nakaz rozpatrywania listów i odpowiedzi na nie w zrozumiałym dla wnioskodawcy języku, czyli rosyjskim.

Okres odwilży wzmógł zainteresowanie miejscowej inteligencji tożsamością etniczną powstała potrzeba podkreślenia azerbejdżańskości w literaturze. Jednym z przykładów tego zjawiska było przyjęcie przez Biuro KC AzPK w styczniu 1956 roku decyzji znoszącej zakaz

\footnotetext{
${ }^{115}$ Za Dzh. Gasanli, Khrushchevskaia ,ottepel'”,... op.cit., s. 145.

${ }^{116}$ Dzh. Gasanli, Khrushchevskaia „ottepel'”... op.cit., s. 151.

117 Konstitutsiia (Osnovnoj Zakon) Gruzinskoj Sovetskoj Sotsialisticheskoj Respubliki, za: http://www.rrc.ge/law/konst_1937_02_13_ru.htm?lawid=1385\&lng_3=ru [18.02.2020]

${ }_{118}$ Konstitutsiia (Osnovnoj Zakon) Armianskoj Sovetskoj Sotsialisticheskoj Respubliki, Armpartizdat, Erevan 1937, s. 30.

${ }^{119}$ D. Katunin, Gosudarstvennij i ofitsialnij iazyk v Konstitutsiiakh stran byvshego SSSR, „Vestnik Tomskogo Gosudarstvennogo Universiteta", 2009, nr 4(8), s. 21.

${ }^{120}$ Dzh. Gasanli, Khrushchevskaia ,ottepel'”... op.cit., s. 177.
} 
eposu Księga Dede Korkuta (Kitab-i Dədə Gorgud) ${ }^{121}$. Z racji tego, że epos odwołuje się do wspólnego dziedzictwa ludów turkijskich, po II wojnie światowej, w okresie zaognienia stosunków turecko-radzieckich, dzieło zostało uznane za pomnik panturkizmu, promujące ideę nacjonalizmu turkijskiego. Po rehabilitacji epos został wydany w dużym nakładzie, azerbejdżańscy naukowcy otrzymali zielone światło na przeprowadzenie i publikowanie wyników badań na łamach gazet i pism, co skutkowało wzmocnieniem świadomości narodowej wśród azerbejdżańskiej ludności.

Tajny referat Chruszczowa uruchamiający proces rehabilitacji ofiar represji stalinowskich w Azerbejdżanie ujawnił się przerwaniem ciszy na temat Narimana Narimanova, lidera azerbejdżańskiej socjaldemokratycznej partii Hummet (az. Hümmət - „energia”), przewodniczącego pierwszego komunistycznego rządu Azerbejdżańskiej SRR (19201922) ${ }^{122}$. Zaznaczmy, że Narimanov nie był ofiarą czystek lat 30., zmarł w 1925 roku i został pochowany z wielką pompą na placu Czerwonym w Moskwie. Jednak z racji krytyki polityki narodowościowej władz moskiewskich był uważany za twarz azerbejdżańskich odchyleńców nacjonalistycznych (nacjonal-uklonizm), a jego dzieła były zakazane ${ }^{123}$. W styczniu 1956 roku pierwszy sekretarz KC AzPK Mustafayev na XXI Zjeździe publicznie oddał cześć Narimanovowi, $\mathrm{z}$ uznaniem podkreślając jego zasługi $\mathrm{w}$ budowaniu miejscowych struktur partyjnych i radzieckiego Azerbejdżanu. W tym samym roku, w kwietniu, zorganizowano $\mathrm{z}$ wielką pompą obchody 85-lecia jego urodzin. $Z$ tej okazji zostały wydane jego dzieła, pojawiły się liczne artykuły publicystyczne, publikacje naukowe opisujące portret polityczny i działalność oświatową lidera azerbejdżańskich komunistów ${ }^{124}$. Można stwierdzić, że kierownictwo ogarnęło narimanofilstwo, zaczęto nadawać ulicom, zakładom pracy, jednostkom administracyjnym imię Narimanova.

Odbudowa politycznego autorytetu Narimanova oznaczała przewartościowanie roli miejscowych komunistów, wywodzących się z partii Hummet, w procesie sowietyzacji kraju. Partyjne kierownictwo w Baku uznało, że konieczne jest przygotowanie fundamentalnej pracy o historii komunistycznej partii Azerbejdżanu. Na podstawie uzyskanych z Moskwy dokumentów z lat 1919-1921 azerbejdżańska filia Intytutu Marksizmu i Leninizmu przy KC AzPK wydała w 1958 roku w dwóch językach Historię Komunistycznej Partii Azerbejdżanu. Publikacja mocno podkreślała decydującą rolę partii Hummat w procesach politycznych początku XX wieku, wysuwając przy tym na pierwszy plan postać lidera partii Narimanova. Książka wywołała irytację i ostrą reakcję Chruszczowa, który uznał, że azerbejdżańscy historycy z przyzwolenia Mustafayeva manipulują historią, wyolbrzymiają rolę Narimanova i partii Hummet, minimalizując tym samym rolę bakińskiego oddziału Rosyjskiej Partii

\footnotetext{
${ }^{121}$ Heroiczny epos, uważany za jeden z najstarszych utworów turkijskiej literatury ludowej. Tekst rękopisu drezdeńskiego, jednego $\mathrm{z}$ dwóch najstarszych zachowanych egzemplarzy utworu, został spisany nie wcześniej niż w XV w, chociaż legendy i baśnie w nim zawarte, zakorzenione w tradycji literatury ustnej, są o wiele starsze. Rękopis nosi tytuł Kitab-i Dadəm Qorqud ala lisan-i taife-i Oğuzan, czyli Księga mojego Dziada Korkuda w języku plemion Oguzów, i zawiera 12 opowiadań. Epos jest uznawany za skarbnicę pamięci kulturowej Turków oguzyjskich, ponieważ odwołuje się do legend i mitów z okresu przedislamskiego.

${ }^{122}$ T. Świętochowski, Azerbejdżan i Rosja. Kolonializm, Islam i Narodowość w Podzielonym Kraju, Istytut Studiów Politycznych, Warszawa 1998, 80; L. Riga, The Bolsheviks and the Russian Empire, Cambridge University Press, Nowy Jork 2012, s. 197-204.

${ }^{123}$ J. Baberowski, Vrag est' vežde. Stalinizm na Kavkaze, Rosspen, Moskva 2010, s. 264-302.

${ }^{124}$ Dzh. Gasanli, Khrushchevskaia ,ottepel'”... op.cit., s. 397-398.
} 
Komunistycznej (bolszewików). W listopadzie 1958 roku do Baku została wydelegowana specjalna komisja, w której skład weszli kierownicy filii Instytutów Marksizmu i Leninizmu oraz specjaliści z innych republik związkowych ${ }^{125}$. Komisja krytycznie wypowiedziała się na temat książki. Policzono nawet, ile razy padło imię Narimanova, co już było według krytyków objawem kultu jednostki.

Powstaje pytanie, dlaczego Moskwa tak ostro zareagowała na rewizję historii partii Hummat i jej lidera Narimana Narimanova? Wydaje się, że w euforii zmian azerbejdżańskie kierownictwo partyjne straciło czujność. Trudno oprzeć się wrażeniu, że Mustafayev błędnie interpretował cele destalinizacji. Mając na celu odsunięcie od władzy swoich rywali, gwardię Stalina, Chruszczow obciążał rządy Stalina za błędy w polityce i gospodarce, nie podważał natomiast tzw. internacjonalizmu bolszewickiego, idei budowania scentralizowanych struktur partyjnych, marginalizujących de facto republiki związkowe. O ile rehabilitacja ofiar stalinizmu lat 30. oskarżonych o zmyślone przestępstwa przeciwko państwu była dopuszczalna, o tyle gloryfikacja polityka, który odważył się na otwartą krytykę polityki bolszewików, wciąż była kontrowersyjna. Aby zrozumieć przyczyny prób wykreślenia Narimanova z historii okresu sowietyzacji, warto przypomnieć sedno konfliktu. W czerwcu 1923 roku Narimanov wysłał do Stalina 40-stronicowy list zatytułowany O historii naszej rewolucji na peryferiach, w którym wskazał błędy popełnione podczas sowietyzacji Azerbejdżanu. Manifest oskarżał centralne władze o kolonialną arogancję. Narimanow pisał, że nacjonalistyczne odchylenie tworzy samo Centrum i jego przedstawiciele $\mathrm{w}$ republikach. „Obrona lokalnych [narodowych - SK] interesów określa się odchyleniem, ale już obrona interesów Rosji Radzieckiej kosztem peryferii - aktem internacjonalizmu" ${ }^{126}$. Autor zarzucał Moskwie faworyzację ormiańskich komunistów w Komitecie Bakijskim partii, dyskryminację języka azerbejdżańskiego, zmniejszenie w szkołach godzin jego nauki na rzecz rosyjskiego. Narimanow wytykał, że pracownicy Azerbejdżanie byli zmuszeni mówić i pisać po rosyjsku, ponieważ Rosjanie, Żydzi i Ormianie nie znali azerbejdżańskiego. Uważał decyzję kierownictwa partii o zwalczaniu obrzędów religijnych za szkodliwą, nieszanującą lokalnych tradycji. Przypomniał tragiczne wydarzenia z marca 1918 roku, gdy bolszewicko-dasznackie bojówki dokonały rzezi na ludności Baku ${ }^{127}$. Stwierdził, że pamięć o tych tragicznych dniach wciąż żyła w społeczeństwie. Dlatego mianowanie Ormian na tak wysokie stanowiska decyzyjne uznał za wyjątkowo nieodpowiedzialne i nietaktowne posunięcie ${ }^{128}$.

Kryzys polityczny na wyższym szczeblu kierownictwa Azerbejdżanu na przełomie lat 1958/1959 obwieszczał zbaczanie z kursu reform, rozpoczętego po słynnym XX Zjeździe. W marcu 1959 roku Rada Najwyższa Azerbejdżańskiej Republiki w ślad za Łotewską SRR przyjęła ustawę o obowiązkowym nauczaniu języka azerbejdżańskiego w rosyjskich szkołach

\footnotetext{
${ }^{125}$ Dzh. Gasanli, Khrushchevskaia „,ottepel'”,... op.cit., s. 512.

${ }^{126}$ N. Narimanov, K istorii nashej revolutsii v okrainakh, w: Nariman Narimanov. Pisma i nekotorye dokumenty po karabakhskomu voprosu, (oprac. Ahmedov Teymur), Nurlan, Baku 2002, s. 44.

127 Szerzej na ten temat patrz: S. Rustamova-Togidi, Mart 1918 g., Baku: Azerbaidzhanskie pogromy v dokumentakh, Baku 2009; A. Balajev, Fevral'skaia rievoliutsia i natsional'nyje okrainy. Martovskie sobytija 1918 goda v Azerbajdzanie, Moskwa, 2008; Y. Mahmudov (ed), Azerbaidzhanskaia Demokraticheskaia Respublika. Arkhivnye dokumenty Velikobritanii, Baku 2008, 70; R. Pipes, The Formation of Soviet Union. Communism and Nationalism 1917-1923, Harvard University Press, Cambridge 1970, 200-201.

${ }^{128}$ N. Narimanov, K istorii nashej revolutsii... op.cit, s. 36-37.
} 
i rosyjskiego $\mathrm{w}$ azerbejdżańskich szkołach. $\mathrm{Na}$ Chruszczowa posypały się skargi o dyskryminacji nieazerbejdżańskiej ludności, o nacjonalizmie azerbejdżańskich władz. Cierpliwość Moskwy już się wyczerpała. Trzydziestego czerwca 1959 roku cały skład Biura Komitetu Centralnego Azerbejdżańskiej Komunistycznej Partii został wezwany do Moskwy na posiedzenie Prezydium KC Partii. Była omówiona sytuacja na Łotwie i w Azerbejdżanie. Azerbejdżańskie kierownictwo oskarżono o samowolę i brak dyscypliny w gospodarce. Ale główne ciosy azerbejdżańska delegacja dostała za błędy w ideologicznej pracy i realizacji narodowej polityki. „Tyle świetnych osób urosło, ale i nawóz w rwącym potoku rozprasza się i krąży w wirze wody. Oczyścimy; jak gospodyni zdejmuje łyżeczką szumowinę i wyrzuca, gdy gotuje barszcz, tak i my zdejmiemy i oczyścimy, a naród w tym nas poprze" ${ }^{, 129}$ skwitował Chruszczow azerbejdżańskie kierownictwo partyjne. Pierwszy sekretarz AzPK próbował się ratować, wydając pod ostrzał byłego już marszałka Prezydium Rady Najwyższej, Mirzę Ibrahimova, inicjatora przyjęcia ustawy o języku urzędowym. Osoby, które głosowały za ustawą i nie miały zastrzeżeń w trakcie dyskusji nad projektem, nagle zaczęły się dystansować i wytykać błędy, domagać się samokrytyki Ibrahimova. Dymisja Ibrahimova i publiczny lincz nad nim i tak nie uratowały głowy Mustafayeva, który zgodnie z tradycją partyjną dokonał samokrytyki i uznał prowadzoną przez jego ekipę politykę narodową za sprzeczną z ideami Lenina.

Można wysunąć tezę, że azerbejdżańskie kierownictwo zostało ofiarą własnego sukcesu, próbując implementować założenia referatu Chruszczowa na grunt Azerbejdżanu. Zwalczało kult Mira Dżafara Bagirova, tak jak Chruszczow chciał zgasić blask Stalina i Berii. I tak jak Chruszczow nie zdawał sobie sprawy ze skutków polityki destalinizacji, tak Imam Mustafayev nie przewidział konsekwencji podnoszenia kwestii języka i spraw narodowych w życiu publicznym i oporu, z jakim spotkały się reformy w Moskwie.

Opublikowana w 2015 roku monografia azerbejdżańskiego historyka Jamila Hasanli Chruszczowowska ,odwilż, i kwestia narodowa w Azerbejdżanie (1954-1959) ${ }^{130}$ ujawnia wiele ciekawych mało znanych faktów, które pokazują, że na kryzys władzy w Baku i zwiększenie presji Moskwy na kierownictwo republiki w dużej mierze miały wpływ wydarzenia październikowe na Węgrzech ${ }^{131}$. W listopadzie i grudniu 1956 roku kierownictwa związkowe i republikańskie nie raz omawiały węgierskie wydarzenia. W raportach służb specjalnych pod tytułem ,tajne” rekomendowano „,natychmiast zacząć przykręcać kurek”. Po węgierskich wydarzeniach 16 listopada 1956 roku kierownik Wydziału KC KPZR ds. współpracy z organami partyjnymi przygotował obszerną analizę wydarzeń wokół przyjęcia ustawy o języku w Azerbejdżanie. Według autorów analizy nie było potrzeby tworzenia takiej ustawy, a jej przyjęcie przyczyniło się do wzrostu nacjonalizmu w Azerbejdżanie. Autorzy dokumentu uznali, że kierownictwo republiki popełniło błąd, przyjmując ustawę bez konsultacji z Centrum oraz wysyłając tekst do innych republik. To sprowokowało bałtyckie republiki do aktywności w tym kierunku. Węgierskie wydarzenia obnażyły połowiczność reform Chruszczowa, który wcale nie dążył do liberalizacji systemu, a wręcz wykorzystał

\footnotetext{
${ }^{129}$ Cytat za Dzh. Gasanli, Khrushchevskaia „ottepel'”... op.cit., s. 574.

${ }^{130}$ Dzh. Gasanli, Khrushchevskaia ,ottepel'”... op.cit., s. 512. W 2015 roku została wydana angielska wersja książki: J. Hasanli, Khrushchev's Thaw and National Identity in Soviet Azerbaijan, 1954-1959, Lexington Books, Lanham 2015.

${ }^{131}$ Dzh. Gasanli, op.cit., s. 217.
} 
rewolucję 1956 roku do wzmocnienia aparatu partyjnego, który całkowicie sobie podporządkował. Trzynastego maja 1957 roku podczas spotkania z zarządem Związku Pisarzy ZSRR wygłosił przemówienie, z którego wynikało, że po Budapeszcie zaczął wyraźnie się dystansować od założeń XX Zjazdu. Stwierdził, że „wrogowie przez Polskę zdobyli tekst referatu, wygłoszonego na zamkniętym posiedzeniu Zjazdu, i liczą na to, że Centralny Komitet, osądzając Stalina, osądził system, i wydarzenia tak się potoczą, że wymkną się spod kontroli tych [Chruszczowa i jego zwolenników - SK], którzy chcieli naprawić błędy Stalina, a oni [wrogowie systemu - SK] pójdą własną drogą. Polska służy dobrym przykładem takiego pojmowania referatu, Węgry - tak samo (...). Istnieją wrogowie i broń trzeba trzymać w pogotowiu, proch trzymać suchy i przede wszystkim trzymać główną broń - ideologiczną broń - w gotowości (...)"132.

$\mathrm{Na}$ przełomie lat 50. i 60 . o nacjonalizm były oskarżane również kierownictwa partyjne Łotwy, Turkmenii, Uzbekistanu, Kirgizji, Tadżykistanu i Mołdowy. Reformy w sferze polityki narodowej Azerbejdżanu pod presją i bezpośrednią ingerencją Moskwy zostały stłumione. Jednak ideologiczne zmiany na rzecz odrodzenia języka, obrony przed rusyfikacją, przywrócenia dziedzictwa ludowego i przemilczanego dorobku Narimana Narimanova były już nieodwracalne. $Z$ perspektywy czasu widać, że te kilka lat w historii Azerbejdżanu miało znaczący wpływ na procesy polityczne lat 80 . i 90 . Efektem odwilży było powstanie fenomenu subkultury sześćdziesiątników, tzw. dzieci XX Zjazdu, pokolenia radzieckiej, w tym azerbejdżańskiej inteligencji, która się sformowała pod wpływem XX Zjazdu, głównie w latach $60 .{ }^{133}$ Większość z nich wypowiadała się za tzw. demokratycznym socjalizmem, czyli umiarkowanymi reformami $\mathrm{w}$ ramach istniejącego systemu. W latach 70 . i 80 . sześćdziesiątnicy zasilili aparat partyjny, media, a przede wszystkim instytuty badawcze oraz uczelnie, tworząc nową retorykę dla przyszłego ruchy antysowieckiego.

\section{Streszczenie:}

Artykuł skupia się na analizie głównych elementów destalinizacji w Azerbejdżanie w epoce Chruszczowa, która charakteryzowała się wzmożeniem aktywności kierownictwa władz partyjnych w dziedzinie społeczno-kulturowej. Praca ukazuje procesy mobilizacji etnicznej zarówno elity partyjnej jak i inteligencji na rzecz odrodzenia języka azerbejdżańskiego, obrony go przed rusyfikacją oraz rewizji problemu natsional-uklonizmu (odchylenia). Celem artykułu jest udzielenie odpowiedzi na pytanie, czy dążenie do azerbejdżanizacji życia publicznego wynikało z "ideałów" władz republiki, czy z dostosowania do warunków polityki "odwilży" Chruszczowa. W związku z tym praca jest próbą odpowiedzi, jak to było możliwe, że inteligencja, wywodząca się z tego samego ustroju polityczno-gospodarczego, przeżyła konflikt z władzą, opowiadając się za odbudową elementów narodowego państwa w ramach ideologii komunistycznej. W nawiązaniu do tak sformułowanego problemu badawczego artykuł stawia tezę, że w odróżnieniu od inteligencji, kierownictwo partyjne w zasadzie odtwarzało w Azerbejdżanie trendy polityki Chruszczowa.

\footnotetext{
${ }^{132}$ Cytat za Dzh. Gasanli, op.cit., s. 319.

133 Aleksandr Shubin, Szestidesiatniki, Encyklopedia BEKM [online] https://megabook.ru/article/\%D0\%A8\%D0\%B5\%D1\%81\%D1\%82\%D0\%B8\%D0\%B4\%D0\%B5\%D1\%81\%D1 $\% 8 F \% D 1 \% 82 \% D 0 \% B D \% D 0 \% B 8 \% D 0 \% B A \% D 0 \% B 8$ [dostep 18.02 .2020$]$
} 


\section{Słowa kluczowe:}

radziecki Azerbejdżan, destalinizacja, Chruszczow, "odwilż", język azerbejdżański, rusyfikacja.

Key words:

Soviet Azerbaijan, distillation, Khrushchev, "thaw", Azerbaijani language, Russification.

\section{Bibliografia:}

1. Baberowski Jörg, Vrag est'vežde. Stalinizm na Kavkaze, Rosspen, Moskwa 2010.

2. Balajev Ajdyn, Fevral'skaia rievoliutsia i natsional'nyje okrainy. Martovskie sobytija 1918 goda v Azerbajdzanie, Moskwa 2008.

3. Blauvelt Timothy, Zmiana statusu i etniczna mobilizacja podczas wydarzeń marca 1956 roku w Gruzji, „Wolność i Solidarność”, 2019, nr 6, s. 48-60.

4. Filtzer Donald, The Khrushchev Era: De-Stalinization and the Limits of Reform in the USSR 1953-64, Macmilian, Londyn 1993.

5. Gasanli Dzhamil, SSSR - Iran: Azerbaidzhan'skij krizis i nachalo kholodnoj vojny (1941-1945 gg.), Geroi Otechestva, Moskwa 2006.

6. Gasanli Dzhamil, Khrushchevskaia „ottepel'” $i$ natsional'nij vopros v Azerbaidzhane (1954-1959), Flinta, Moskwa 2009.

7. Gaziian Alvard (oprac. i red.), Pis'ma Katolikosa vsekh armian Vazgena I Predsedateliu Soveta Ministrov SSR N. A. Bulganinu, „Patma-Banasirakan Handes” (Historyczno-Filologiczne Pismo) 2000, $\mathrm{nr} \quad 2$, s. 249-255 http://hpj.asjoa.am/4518/1/2000-2(249).pdf [18.02.2020].

8. Hasanli Jamil, Khrushchev's Thaw and National Identity in Soviet Azerbaijan, 19541959, Lexington Books, Lanham 2015.

9. Ismailov Eldar, Istoria „bolshogo terrora” w Azerbaidzhanie, Rosspen, Moskwa 2015.

10. Ismailov Eldar, Soviet "State Terrorism in Azerbaijan, „The Caucasus and Globalization" 2010, t. 4. nr 1-2, s. 163-172.

11. Jones Polly, Introduction: the dilemas od De-Stalinization, w: Jones Polly (red.), The Dilemmas of De-Stalinization: Negotiating Cultural and Social Change in the Khrushchev era, Routledge, Londyn 2006, s. 1-18.

12. Jones Polly, From the secret speech to the burial of Stalin: real and ideal responses to de-Stalinization, w: Jones Polly (red.), The Dilemmas of De-Stalinization: Negotiating Cultural and Social Change in the Khrushchev era, Routledge, Londyn 2006.

13. Katunin Dmitrij A., Gosudarstvennyj $i$ ofitsialnyj iazyk $v$ Konstitutsiiakh stran byvshego SSSR, „Vestnik Tomskogo Gosudarstvennogo Universiteta”, 2009, nr 4(8), s. 20-29.

14. Konstitutsiia (Osnovnoj Zakon) Armianskoj Sovetskoj Sotsialisticheskoj Respubliki, Armpartizdat, Erewań 1937. 
15. Mahmudov Yagub (red), Azerbaidzhanskaia Demokraticheskaia Respublika. Arkhivnye dokumenty Velikobritanii, Baku 2008.

16. Narimanov Nariman, $K$ istorii nashej revolutsii v okrainakh, w: Nariman Narimanov. Pisma i nekotorye dokumenty po karabakhskomu voprosu, (oprac. Ahmedov Teymur), Nurlan, Baku 2002, s. 3-80.

17. Pipes Richard, The Formation of Soviet Union. Communism and Nationalism 19171923, Harvard University Press, Cambridge 1970.

18. Reynolds Dawid A. J., Revising History in Communist Europe: Constructing CounterRevolution in 1956 and 1968, Althem Press, Nowy Jork 2020.

19. Riga Liliana, The Bolsheviks and the Russian Empire, Cambridge University Press, Nowy Jork 2012.

20. Rustamova-Togidi Solmaz, Mart 1918 g., Baku: Azerbaidzhanskie pogromy v dokumentakh, Baku 2009.

21. Świętochowski Tadeusz, Azerbejdżan i Rosja. Kolonializm, Islam i Narodowość w Podzielonym Kraju, Instytut Studiów Politycznych, Warszawa 1998.

22. Taubman William, Chruszczow. Człowiek i epoka, tłum., Łukasz Witczak, Bukowy Las, Wrocław 2012.

23. Konstitutsiia (Osnovnoj Zakon) Gruzinskoj Sovetskoj Sotsialisticheskoj Respubliki, http://www.rrc.ge/law/konst_1937_02_13_ru.htm?lawid=1385\&lng_3=ru [18.02.2020]

24. Aleksandr Shubin, Szestidesiatniki, Encyklopedia BEKM [online] https://megabook.rularticle $\%$ D0\%A8\%D0\%B $\% \% D 1 \% 81 \% D 1 \% 82 \% D 0 \% B 8 \% D 0 \% B$ $4 \% D 0 \% B 5 \% D 1 \% 81 \% D 1 \% 8 F \% D 1 \% 82 \% D 0 \% B D \% D 0 \% B 8 \% D 0 \% B A \% D 0 \% B 8$ [dostep 18.02.2020] 
